\title{
Comparison of virus- and bacterivory-induced bacterial mortality in the eutrophic Masan Bay, Korea
}

\author{
Dong H. Choi, Chung Y. Hwang, Byung C. Cho* \\ Molecular and Microbial Ecology Laboratory, School of Earth and Environmental Sciences and Research Institute of \\ Oceanography, Seoul National University, Seoul 151-742, Republic of Korea
}

\begin{abstract}
Characteristics of viral ecology and the relative importance of virus- and bacterivoryinduced bacterial mortality were investigated in surface and hypoxic layers of the eutrophic Masan Bay, Korea, in summer 1999. During the study, environmental and microbial variables changed strongly in the bay. However, the viral to bacterial abundance ratio (VBR) mostly varied less than 3fold even in a declining phase of viruses and bacteria, indicating a tight coupling between bacterial and viral assemblages. Comparisons of viral lysis and heterotrophic nanoflagellate (HNF) grazing rates showed that viruses exerted a small (average $9.4 \%$, range 1.6 to $34.4 \%, \mathrm{n}=29$ ) but relatively constant control on bacterial production in the bay, whereas HNF exerted a highly variable (average $41 \%$, range 0.3 to $183.4 \%, n=17$ ) effect on the mortality of bacteria. However, the relative ratios of virus- to HNF-induced bacterial mortality varied from 0.03 to 2.0, comparable to a range reported for open ocean waters, except for 2 data of 17.9 and 24.5 from low-salinity conditions. Overall, virusbacteria-HNF interactions in the bay seemed to be generally regulated in a steady-state situation.
\end{abstract}

KEY WORDS: Viruses $\cdot$ Heterotrophic nanoflagellate $\cdot$ Bacterial mortality $\cdot$ Hypoxia $\cdot$ Bay

Resale or republication not permitted without written consent of the publisher

\section{INTRODUCTION}

It is now well recognized that both viruses and heterotrophic nanoflagellates (HNF) are important agents of bacterial mortality in the sea. This view has been made mainly based on studies done in micro- or mesocosms (Bratbak et al. 1992, Fuhrman \& Noble 1995, Guixa-Boixereu et al. 1999, Tuomi \& Kuuppo 1999, Almeida et al. 2001). These studies in coastal environments show that viruses have a similar impact on bacterial mortality as does bacterivory (Fuhrman \& Noble 1995, Tuomi \& Kuuppo 1999, Almeida et al. 2001). Other micro- or mesocosm studies show that viruses are the dominant source of bacterial mortality (Bratbak et al. 1992, Guixa-Boixereu et al. 1999), especially in a non-steady-state situation, such as that during a phytoplankton bloom (Guixa-Boixereu et al. 1999). In addi-

${ }^{*}$ Corresponding author. Email: bccho@plaza.snu.ac.kr tion, a field study conducted in the Bering and Chukchi Seas also suggested that the role of viruses in bacterial mortality was similar to that of bacterivory in surface waters (Steward et al. 1996), albeit bacterivory due to HNF was calculated by assuming a constant clearance rate of $10 \mathrm{nl} \mathrm{HNF}{ }^{-1} \mathrm{~h}^{-1}$ in that study. Thus, only a few simultaneous measurements of virus- and bacterivoryinduced bacterial mortality have been made in marine environments. Therefore, we still lack information on how the relative contribution of viral lysis and bacterivory to bacterial mortality varies and which factors are important in such variations.

Virus-bacteria-HNF interactions are particularly unknown in hypoxic seawaters. Since hypoxia is widely observed and expected to increase in coastal and estuarine waters (Seki 1991, Paerl et al. 1998), and since virus-bacteria-HNF interactions are fundamental processes in the material flow in aquatic systems, it is necessary to investigate virus-bacteria-HNF interactions under hypoxic conditions. To accomplish this goal, we 
first determined whether or not HNF in hypoxic zones actively grazed on bacteria and if they were sensitive to low oxygen conditions. This aspect is discussed in Park \& Cho (2002). Here, our main aims were to elucidate the characteristics of viral ecology in a eutrophic bay, and to determine how the relative significance of viral lysis and HNF bacterivory for bacterial mortality varied in a bay in which hypoxic conditions develop every summer.

\section{MATERIALS AND METHODS}

Study area and sample collection. The Masan Bay is located on the southern coast of Korea and is a semienclosed inner bay with an area of $33.8 \mathrm{~km}^{2}$ and an average depth of ca. $15 \mathrm{~m}$ (Park \& Cho 2002). The bay is highly eutrophic. Hypoxic conditions $\left(<4 \mathrm{mg} \mathrm{O}_{2} \mathrm{l}^{-1}\right.$, Paerl et al. 1998) are usually found during summer every year, and anoxia often develops at the bottom in late summer (Jin et al. 2000, Park \& Cho 2002). Seawater samples were collected with 51 Niskin bottles. On 26 May, samples were collected at Stns B $\left(35^{\circ} 11^{\prime}\right.$ $\left.55^{\prime \prime} \mathrm{N}, 128^{\circ} 35^{\prime} 4^{\prime \prime} \mathrm{E}\right)$ and D (359' $\left.7^{\prime \prime} \mathrm{N}, 128^{\circ} 36^{\prime} 26^{\prime \prime} \mathrm{E}\right)$, but later only at Stn B because variations between the 2 stations were small (see 'Results'). To avoid introducing oxygen during handling, hypoxic water samples were gently drained from the Niskin bottle into 21 biochemical oxygen demand (BOD) bottles using silicon tubing, and overflowing was allowed. Samples from the hypoxic zone were brought to the land-based laboratory within $2 \mathrm{~h}$. We checked dissolved oxygen (DO) concentration in the bottles at the laboratory before carrying out the experiments. The changes were small $\left(\right.$ mean $\pm \mathrm{SD}, 0.1 \pm 0.2 \mathrm{mg} \mathrm{l}^{-1}$ ) in samples from May and early August, but there were some increases $(1.1 \pm 0.6$ $\mathrm{mg} \mathrm{l}^{-1}$ ) in most samples from June and late August, probably due to introduction of air during the handling of samples. Although DO changed to some extent in samples from the hypoxic zone, hypoxic conditions seemed to be maintained during the sampling and transportation of samples. Each sample was used for determining abundance and production of viruses and bacteria, and HNF abundance and grazing.

Viral abundance and production. Samples for measurements of viral abundance (VA) were fixed with $0.02 \mu \mathrm{m}$ filtered, borate-buffered formalin (final concentration, 2\%). Viruses were stained with SYBR Green I (final dilution, $2.5 \times 10^{3}$ fold) and enumerated by epifluorescence microscopy (EM) as described by Noble \& Fuhrman (1998). Samples for determination of frequency of visibly infected bacteria (FVIB) were preserved with EM grade glutaraldehyde (final concentration, $2 \%$ ), and stored in sterile polypropylene centrifuge tubes at $4^{\circ} \mathrm{C}$. By centrifugation (Beckman
XL-90) using a swing bucket rotor (SW 41) at $30000 \times$ $g$ for $30 \mathrm{~min}$ at $20^{\circ} \mathrm{C}$, bacteria were collected onto formvar-coated, 400 mesh electron microscope grids that were made evenly hydrophilic by floating on a drop of $1 \%$ poly-L-Lysine for $1 \mathrm{~min}$ (Suttle 1993). In some cases, we diluted the samples with $0.02 \mu \mathrm{m}$ filtered seawater to decrease interference of the particles. Grids were stained for $20 \mathrm{~s}$ with $0.5 \%$ uranyl acetate followed by 3 sequential rinses with $0.02 \mu \mathrm{m}$ filtered Milli- $Q^{\circledR}$ water. Air-dried grids were examined under a JEOL 2000 EXII transmission electron microscope (TEM) at an accelerating voltage of $100 \mathrm{kV}$. Using TEM at 30000 to $50000 \times$ magnification, 300 to 500 cells per sample were examined for enumeration of infected cells. Cells were scored as infected if they contained 3 or more intracellular viruses. Bacterial mortality due to viral lysis was estimated according to Binder (1999), assuming that infected and uninfected bacteria were grazed at the same rate. Viral production was estimated by multiplying burst size, the fraction of mortality due to viral lysis and bacterial production (Noble \& Steward 2001). Burst size was estimated as the average number of virus-like particles observed in all visibly infected cells.

Bacterial abundance and production. Samples for measurements of bacterial abundance (BA) were fixed with $0.02 \mu \mathrm{m}$ filtered, borate-buffered formalin (final concentration, $2 \%$ ). Bacteria were stained with DAPI (4', 6-diamidino-2-phenylindole; final concentration, $1 \mu \mathrm{g} \mathrm{ml}^{-1}$ ), collected on black $0.2 \mu \mathrm{m}$ polycarbonate filter and counted under UV excitation using an EM (Porter \& Feig 1980). Bacterial production was measured by the [ ${ }^{3} \mathrm{H}$-methyl]thymidine (TdR) incorporation method (Ducklow et al. 1992). Water samples from the hypoxic zone were handled in a chamber in which $\mathrm{O}_{2}$ concentration was adjusted with $\mathrm{N}_{2}$ gas to in situ DO \% saturation and monitored with an oxygen probe (Model XO-326AL, New Cosmos Electric). Five ml of hypoxic samples in serum vials sealed with a silicone stopper and aluminum seal, and $5 \mathrm{ml}$ of surface samples in sterile tubes, were incubated in triplicate with 160 to $200 \mathrm{nM}$ of TdR (i.e. $10 \mathrm{nM}$ of hot TdR and 150 to $190 \mathrm{nM}$ of cold TdR). All samples were incubated in the dark for ca. $30 \mathrm{~min}$ at in situ water temperature. Formalin-killed samples (final concentration, 2\%) served as blanks. After incubation, TdR incorporation was stopped by adding formalin. The samples were kept cool on ice, filtered onto $25 \mathrm{~mm}, 0.22 \mu \mathrm{m}$ cellulose nitrate filter (Whatman), rinsed with 5\% ice-cold trichloroacetic acid and subsequently, 80\% ice-cold ethanol, after which they were radio-assayed as according to Ducklow et al. (1992). The isotope dilution approach (Moriarty 1990) was performed with 1 sample from the surface and the hypoxic layer to evaluate the dilution pool of TdR. The samples were incubated 
in triplicate with $\left[{ }^{3} \mathrm{H}\right.$-methyl]TdR (final concentration, $10 \mathrm{nM}$ ) diluted with increasing amounts of unlabeled TdR (0 to $190 \mathrm{nM}$ ), and treated as above. TdR incorporation rates were calculated by using specific activities corrected for the isotope dilution measured in each layer and converted to cell number produced with a conversion factor $\left(0.5 \times 10^{18}\right.$ cells mol $^{-1}$ TdR incorporated) that would have no isotope dilution in it (Cho \& Azam 1988, Moriarty 1990). Since TdR incorporation rates measured by the isotope dilution approach were similar to those measured with high concentrations of TdR (authors' unpubl. data), the use of high concentration of TdR might not be a problem.

Abundance and grazing rates of HNF. Detailed descriptions of the methods used to determine HNF abundance and grazing rates can be found in Park \& Cho (2002). Briefly, primulin-stained HNF were collected (filtered volume of 10 to $15 \mathrm{ml}$ ) on $0.4 \mu \mathrm{m}$ polycarbonate filters and enumerated at 1000× magnification with UV excitation using an EM (Bloem et al. 1986). HNF grazing rates on bacteria were measured by using fluorescent-labeled bacteria (FLB) prepared as according to Sherr et al. (1987). FLB uptake experiments were carried out in duplicate $250 \mathrm{ml}$ polycarbonate bottles presoaked in $10 \% \mathrm{HCl}$ and rinsed with deionized water. The added FLB was between 4 and $14 \%$ of total BA. Grazing experiments were conducted in the dark at in situ temperature. Hypoxic samples for the measurements of HNF grazing were handled inside a chamber in the laboratory. At $0,10,20$ and $30 \mathrm{~min}, 30 \mathrm{ml}$ subsamples were collected, fixed and kept refrigerated until microscopic examinations. Subsamples were primulin stained and filtered, and at least 150 microscopic fields were counted. The numbers of FLB contained within the HNF were counted under blue excitation light. We calculated per cell clearance rates as described in Sherr et al. (1987). Grazing rates were calculated by multiplying the per cell clearance rates by the total BA and the HNF abundance in the samples.

Viral contact rates. The contact rate $(\mathrm{R})$ between viruses and bacteria was calculated by formulae as according to Murray \& Jackson (1992). Briefly, R = $\left(\mathrm{Sh} 2 \pi d D_{\mathrm{v}}\right) V B$, where $\mathrm{Sh}$ is the Sherwood number of 1.06 (assuming that $10 \%$ of motile cells consist of a bacterial community; Wilhelm et al. 1998), $d$ is the bacterium diameter (calculated from the mean bacterial cell volume determined for each sample (Park \& Cho 2002), assuming that the cells are spheres), $V$ and $B$ are the VA and the BA, respectively. $D_{V}$ is the diffusivity of viruses and $D_{V}=\mathrm{k} T / 3 \pi \mu d_{\mathrm{v}}$, where $\mathrm{k}$ is the Boltzmann constant $\left(1.38 \times 10^{-23} \mathrm{~J} \mathrm{~K}^{-1}\right), T$ is the in situ temperature (in degrees Kelvin), $\mu$ is the viscosity of seawater (in Pa $\mathrm{s}^{-1}$; Dera 1992), and $d_{\mathrm{v}}$ is the average diameter of the viral capsid observed during the study $(62 \pm 31 \mathrm{~nm}, \mathrm{n}=$
11; C. Y. Hwang unpubl. data). The contact rate was divided by BA to estimate the viral contact rate per bacterium on a daily base.

Other analyses. Concentrations of chlorophyll a (chl a) were measured spectrophotometrically as according to Parsons et al. (1984). For the details of DO measurements, refer to Park \& Cho (2002). Analyses of variance (ANOVA) and Mann-Whitney $U$-tests were performed using the SPSS program for Windows (version 8.0, SPSS). Model II regression was performed using the Model II Regression program available at www.fas. umontreal.ca/biol/legendre.

\section{RESULTS}

\section{Hydrography and DO concentrations}

During the study period, the surface layer (1 to $4 \mathrm{~m}$ ) was less saline and warmer than the hypoxic bottom layer, and hypoxic conditions $\left(0.2\right.$ to $\left.3.9 \mathrm{mg} \mathrm{O}_{2} \mathrm{l}^{-1}\right)$ persisted in the bottom layer. For more details, see Park \& Cho (2002). Briefly, temperature gradually increased by ca. 5 to $7^{\circ} \mathrm{C}$ from May to late August. Salinity in the surface layer decreased from 29.0 (May) to $23.0 \mathrm{psu}$ (June) and then to between 6.1 and 9.9 psu (early August) due to the rainy season (120 and $268 \mathrm{~mm}$ rainfall on 17 June and 30 July in the study area), and then increased to $25.0 \mathrm{psu}$ in late August. Salinity in the hypoxic zone was 31.9 to $33.1 \mathrm{psu}$ in May and June, but decreased to between 25.5 and 29.8 psu in August.

\section{Chl a}

Concentration of chl a varied widely during the study period: on 26 May, the concentration was high in the surface layer, but then decreased to a low level in June (Fig. 1A). Afterwards, the chl a concentration continually increased to the highest value in late August. Thus, the bay was highly eutrophic in May and late August. In the hypoxic layer, chl a was relatively low and constant throughout the investigation period.

\section{Abundances, abundance ratios and encounter rates of viruses and bacteria}

VA in the surface layer were either higher than or similar to those in the hypoxic layer (Table 1). The highest VA was found at $1 \mathrm{~m}$ depth at Stn B in May and the lowest at $7 \mathrm{~m}$ depth at Stn B on the 1 August (Table 1). The highest and lowest BA were found at the surface at Stn B in May and early August, respectively (Table 1). 

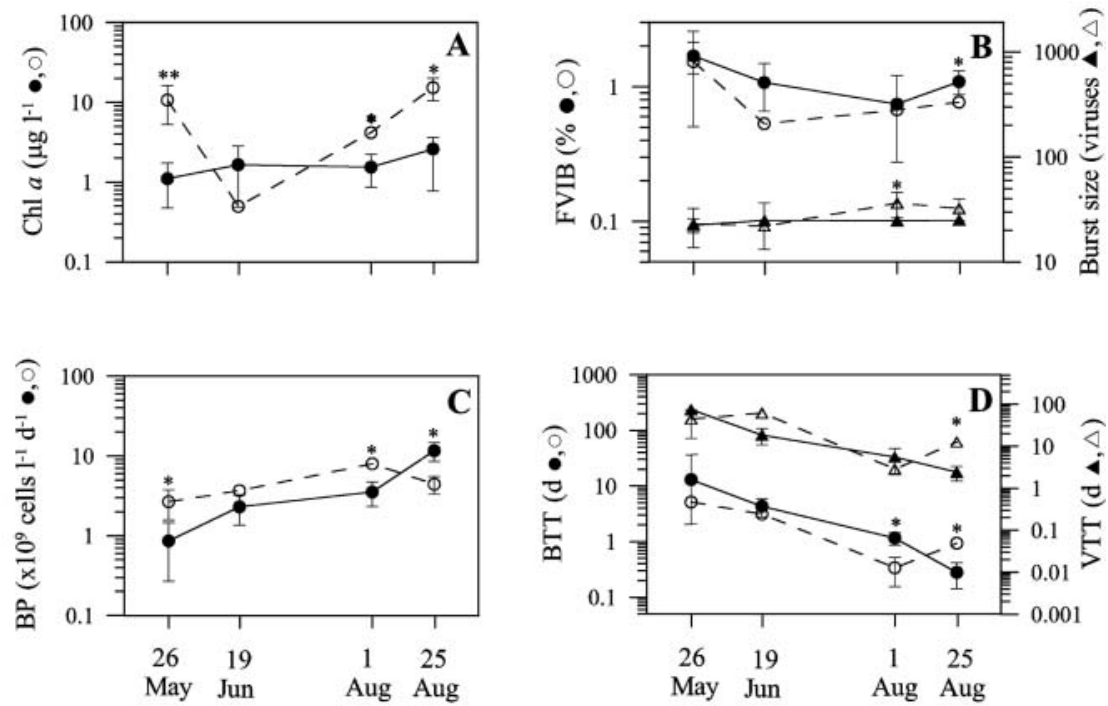

Fig. 1. Temporal variations in Masan Bay. (A) Chlorophyll a (chl a), (B) frequency of visibly infected bacteria (FVIB) and burst size, (C) bacterial production (BP), and (D) turnover times of bacteria (BTT) and viruses (VTT). Open and closed symbols represent samples from oxic and hypoxic layers, respectively. On 26 May 1999, averaged data of Stns B and D are shown; for all other dates, averaged data of Stn B only is provided. Significant differences between 2 layers in each investigation are marked $\left({ }^{* *} p<0.001,{ }^{*} p<0.05\right)$. Error bars represent $1 \mathrm{SD}$, no error bars denote that $1 \mathrm{SD}$ is smaller than symbol size were higher than those in the hypoxic zone (Fig. 1B). Burst size did not significantly (ANOVA, $\mathrm{p}=0.13$ ) change with time in the 2 layers (Fig. 1B).

\section{Bacterial production}

Bacterial production in the surface layer fluctuated within a range of 1.2 to $8.8 \times 10^{9}$ cells $^{-1} \mathrm{~d}^{-1}$, whereas bacterial production in the hypoxic layer ( 0.3 to $12.7 \times 10^{9}$ cells s $^{-1} \mathrm{~d}^{-1}$ ) tended to steadily increase during the investigation period (Fig. 1C). Thus, in late August, bacterial production was higher in the hypoxic than in the surface layer (Fig. 1C). The bacterial production rates corresponded to turnover times of bacteria ranging from 0.2 to $7.7 \mathrm{~d}$ and from 0.2 to $34.2 \mathrm{~d}$ in surface and hypoxic layer, respectively (Fig. 1D). Turnover times of bacteria decreased with time in the 2 layers, but increased somewhat in the surface layer in late August.
BA were not statistically different between surface and hypoxic layers (Mann-Whitney $U$-test, p > 0.05) except in May (Table 1). The viral to bacterial abundance ratios (i.e. VBR) in surface and hypoxic layers were not statistically different (Mann-Whitney $U$-test, p > 0.05) in June and late August. However, in May and early August, the VBRs were statistically different between the 2 layers (Table 1). VBR mostly varied less than 3fold in the water column, except for 3 low ratios (3.3, $3.4,4.2$ ) found in hypoxic samples in June and early August (Table 1). Viral contact rates of bacteria were highest in the surface layer in May and lowest in the hypoxic zone in early August (Table 1). The encounter rates in the hypoxic zone showed a tendency to become lower in August compared to those in May and June (Table 1).

\section{Frequency of visibly infected bacteria and burst size}

FVIB ranged from 0.5 to $3.5 \%$ in the surface layer and 0.2 to $2.3 \%$ in the hypoxic layer. FVIB was not statistically different between the 2 layers, except in late August (Fig. 1B). Burst size ranged from 14 to 46 and 14 to 39 in surface and hypoxic layers, respectively. In general, burst size was not significantly different (Mann-Whitney $U$-test, $\mathrm{p}>0.05$ ) between the 2 layers, but in early August, the values in the surface layer

\section{Production of viruses}

The estimated production of viruses fluctuated within a range of 2.0 to $24.2 \times 10^{9}$ viruses $\mathrm{l}^{-1} \mathrm{~d}^{-1}$ in the surface layer, whereas it varied within a small range of 1.3 to $7.2 \times 10^{9}$ viruses $\mathrm{l}^{-1} \mathrm{~d}^{-1}$ in the hypoxic layer from May to early August, but increased to the highest value of 33.5 $\times 10^{9}$ viruses $\mathrm{l}^{-1} \mathrm{~d}^{-1}$ in late August (Table 1). Turnover times of viruses ranged from 2.6 to $96.3 \mathrm{~d}$ and 1.8 to $138.4 \mathrm{~d}$ in the surface and hypoxic layers, respectively (Fig. 1D). Turnover times of viruses tended to decrease with time in the 2 layers (Fig. 1D), but in the surface layer, it increased again in late August.

\section{Bacterial mortality}

Bacterial mortality due to viral lysis (i.e. \% of bacterial production lost due to viral lysis) ranged from 4.0 to $34.4 \%$ in the surface layer and from 1.6 to $19.8 \%$ in the hypoxic layer (Fig. 2) with no significant differences between the 2 layers (Mann-Whitney $U$-test, p > 0.05). Viruses seemed to control only a small fraction (mean \pm $\mathrm{SD}, 9.4 \pm 6.4 \%, \mathrm{n}=29$ ) of bacterial production in both layers. However, bacterial mortality due to HNF grazing (i.e. \% of bacterial production lost due to HNF grazing) varied greatly with time (Fig. 2). In May, it was between 160.5 and $183.4 \%$ in the surface layer, 
indicating that HNF grazing was a predominant source of bacterial mortality at that time. In June, when salinity significantly decreased in the surface layer (i.e. $23.0 \mathrm{psu}$ ), mortality due to HNF grazing decreased to $16.0 \%$. In August, HNF grazing became a minor source of bacterial mortality (2.7 to $6.2 \%$ in the surface and 0.3 to $11.8 \%$ in hypoxic layer). Thus, the virus-toHNF mortality ratios were $>1$ in August when low salinity was found in the water-column, and increased to 24.5 in the hypoxic layer in late August.

\section{Correlations}

The only significant correlation observed between bacteria and virus variables was the relationship between BA and VA for surface samples (Fig. 3A). No significant correlation was found between bacteria and virus variables for the hypoxic samples. The ratios of bacterial mortality due to viruses and to bacterivory correlated significantly with salinity in both hypoxic and surface layers (Fig. 3B).

\section{DISCUSSION}

\section{Interactions among viruses, bacteria and HNF in a non-steady state bay}

In coastal waters, it is believed that steady state would seldom be attainable (Fenchel et al. 1990). In fact, environmental and microbial variables changed widely in the summer in Masan Bay: salinity varied within a range of 6.1 to $32.4 \mathrm{psu}$, and chl a concentration varied 42-fold in the surface layer. VA and BA varied 24- and 10-fold, and turnover times of VA and BA varied 52- and 38-fold, respectively. Thus, a nonsteady-state situation, in which a large temporal fluc-

Table 1. Abundance of viruses (VA) and bacteria (BA), the ratio of VA to BA (VBR), viral contact rates (VCR) of bacteria, abundance (HNFA) and clearance rates (CR) of heterotrophic nanoflagellate (HNF), grazing rates on viruses (GR virus $_{\text {s }}$ by $\mathrm{HNF}_{\text {and viral }}$ production (VP) in Masan Bay. Numbers in bold represent data from the hypoxic layers. nd: no data

\begin{tabular}{|c|c|c|c|c|c|c|c|c|c|c|}
\hline $\begin{array}{l}\text { Date } \\
\quad \text { Stn }\end{array}$ & $\begin{array}{l}\text { Depth } \\
\text { (m) }\end{array}$ & $\begin{array}{c}\text { VA } \\
\left(\times 10^{10}\right. \\
\left.\text { viruses } \mathrm{l}^{-1}\right)\end{array}$ & $\begin{array}{c}\text { BA } \\
\left(\times 10^{9}\right. \\
\left.\text { cells } \mathrm{l}^{-1}\right)\end{array}$ & VBR & $\begin{array}{c}\text { VCR } \\
\left(\text { cell }^{-1} d^{-1}\right)\end{array}$ & $\begin{array}{c}\mathrm{CR}^{\mathrm{a}} \\
\left(\mathrm{nl} \mathrm{HNF} \mathrm{HN}^{-1}\right. \\
\left.\mathrm{h}^{-1}\right)\end{array}$ & $\begin{array}{l}\mathrm{HNFA}^{\mathrm{a}} \\
\left(\times 10^{6}\right. \\
\left.\mathrm{HNF}^{-1}\right)\end{array}$ & $\begin{array}{c}\mathrm{GR}_{\text {virus }}{ }^{\mathrm{b}} \\
\left(\times 10^{9} \text { viruses }\right. \\
\left.\mathrm{l}^{-1} \mathrm{~d}^{-1}\right)\end{array}$ & $\begin{array}{c}\text { VP } \\
\left(\times 10^{9} \text { viruses }\right. \\
\left.\mathrm{l}^{-1} \mathrm{~d}^{-1}\right)\end{array}$ & $\frac{\mathrm{GR}_{\text {virus }}{ }^{\mathrm{b}}}{\mathrm{VP}}$ \\
\hline \multicolumn{11}{|c|}{26 May 99} \\
\hline \multirow[t]{4}{*}{ B } & 0 & 21.6 & 16.4 & 13.2 & 269 & 7.0 & 4.0 & 5.8 & 11.2 & 0.5 \\
\hline & 1 & 26.8 & 15.8 & 17.0 & 321 & nd & 4.5 & nd & 24.2 & - \\
\hline & 6 & 18.2 & 9.3 & 19.5 & 303 & nd & 0.8 & nd & 1.3 & - \\
\hline & 8 & 16.9 & 6.2 & 27.3 & 267 & 5.2 & 0.8 & 0.7 & 4.5 & 0.2 \\
\hline \multirow[t]{5}{*}{$\mathrm{D}$} & 0 & 20.2 & 9.1 & 22.1 & 237 & 4.7 & 3.0 & 2.7 & 3.3 & 0.8 \\
\hline & 1 & 20.0 & 10.3 & 19.4 & 227 & nd & 3.1 & nd & 3.5 & - \\
\hline & 2 & 18.9 & 12.3 & 15.4 & 237 & nd & 2.7 & nd & 2.0 & - \\
\hline & 7 & 12.0 & 4.8 & 25.2 & 199 & nd & 0.8 & nd & 1.3 & - \\
\hline & 10 & 6.9 & 3.0 & 22.9 & 119 & 5.3 & 0.9 & 0.3 & 2.5 & 0.1 \\
\hline \multicolumn{11}{|c|}{19 Jun 99} \\
\hline \multirow[t]{5}{*}{ B } & 0 & 19.9 & 11.4 & 17.4 & 239 & 1.8 & 1.2 & 0.4 & 3.2 & 0.1 \\
\hline & 1 & 14.3 & 9.8 & 14.5 & 184 & 7.1 & 0.9 & 0.8 & 4.9 & 0.2 \\
\hline & 3 & 8.9 & 8.7 & 10.3 & 98 & 8.8 & 0.5 & 0.4 & 4.8 & 0.1 \\
\hline & 5 & 5.9 & 8.3 & 7.1 & 56 & 7.3 & 0.5 & 0.2 & 2.7 & 0.1 \\
\hline & 7 & 2.8 & 8.7 & 3.3 & 30 & 9.9 & 0.6 & 0.1 & 10.5 & 0.01 \\
\hline \multicolumn{11}{|c|}{1 Aug 99} \\
\hline \multirow[t]{5}{*}{ B } & 0 & 3.4 & 1.6 & 21.4 & 65 & 3.0 & 1.8 & 0.2 & 10.5 & 0.01 \\
\hline & 1 & 5.2 & 2.5 & 20.6 & 103 & 2.6 & 1.9 & 0.2 & 20.3 & 0.01 \\
\hline & 3 & 1.7 & 4.0 & 4.2 & 16 & nd & 0.7 & nd & 1.8 & - \\
\hline & 5 & 3.3 & 4.1 & 8.0 & 33 & 10.4 & 0.4 & 0.1 & 7.2 & 0.02 \\
\hline & 7 & 1.1 & 3.4 & 3.4 & 12 & 7.5 & 0.4 & 0.03 & 4.3 & 0.01 \\
\hline \multicolumn{11}{|c|}{25 Aug 99} \\
\hline \multirow[t]{5}{*}{ B } & 0 & 10.5 & 3.9 & 26.5 & 202 & 0.7 & 1.8 & 0.1 & 6.8 & 0.02 \\
\hline & 1 & 9.5 & 3.8 & 25.1 & 86 & 1.0 & 1.9 & 0.2 & 6.7 & 0.03 \\
\hline & 3 & 12.7 & 4.7 & 27.0 & 112 & nd & 0.9 & nd & 33.5 & - \\
\hline & 4 & 4.1 & 2.0 & 20.3 & 36 & 2.1 & 0.3 & 0.03 & 18.9 & 0.002 \\
\hline & 6 & 2.9 & 2.3 & 12.7 & 27 & 2.2 & 0.3 & 0.02 & 31.0 & 0.001 \\
\hline
\end{tabular}



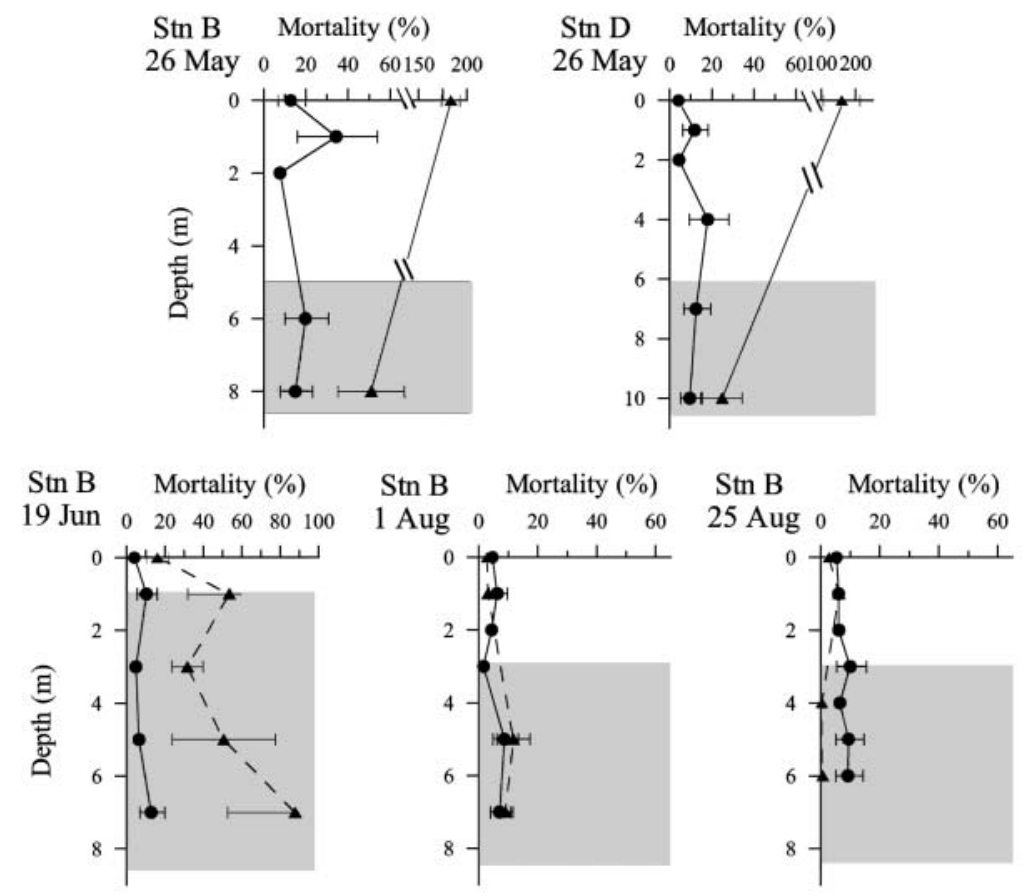

Fig. 2. Depth variations of the percentage of bacterial production lost due to viral lysis $(\bullet)$ or to heterotrophic nanoflagellate grazing (४) in Masan Bay during summer in 1999 at Stns B and D. Shaded areas represent hypoxic layers. Error bars for viral lysis represent the ranges calculated according to Binder (1999) using the low (0.73) and high (0.86) values of the fraction of the latent period during which viral particles are not visible (Proctor et al. 1993). Error bars for grazing represent $1 \mathrm{SD}$ of duplicates

tuation of variables occurred, seemed to have occurred during the study period. However, interestingly, the variations of relative importance of viral lysis to HNF grazing in bacterial mortality in the bay were generally comparable (0.03 to 2.0) to those found in open seawaters in the Bering and Chukchi Seas (0.08 to 12.2;
Steward et al. 1996), where steady state would be more plausible than in bay waters. Two exceptionally high ratios of 17.9 and 24.5 were found in low salinity ( $27 \mathrm{psu})$, hypoxic waters in late August. High ratios (ca. 5 to 9) of lysis to bacterivory loss-rate were observed in a non-steady-state situation during a postbloom period in a coastal microcosm (Guixa-Boixereu et al. 1999). Maybe low salinity conditions in the bay brought about a nonsteady-state situation in which suppressions of bacterivory (Fig. 2), and thus, high mortality ratios were observed (Fig. 3B). Overall, virus-bacteria-HNF interactions in the bay were generally regulated in a steady-state situation.

Two characteristics of viral ecology observed in the bay were noteworthy. Small (mostly $<3$ fold) variations in VBR despite high variations of VA and BA (24- and 10-fold, respectively) suggest that a tight coupling between bacterial and viral assemblages was maintained during the study. Such a small variation of VBR in coastal and bay waters is not uncommon (Table 2). However, it is remarkable that the tight coupling (i.e. small variations of VBR) was maintained even in a decreasing phase of both BA and VA from June to early August. In addition, viruses exerted a small but relatively constant control on bacterial production in the water column in the widely changing bay environment, whereas HNF exerted highly variable mortality of bacteria. At high BA in May and June,

Table 2. Variations of viral abundance (VA), bacterial abundance (BA), ratios of VA to BA (VBR) and viral contact rates (VCR) observed during summer in various coastal and estuarine waters

\begin{tabular}{|c|c|c|c|c|c|c|}
\hline Location & Month & $\begin{array}{c}\text { VA } \\
\left(\times 10^{10} \text { viruses } l^{-1}\right)\end{array}$ & $\begin{array}{c}\text { BA } \\
\left(\times 10^{9}{\left.\text { cells } 1^{-1}\right)}^{-1}\right.\end{array}$ & VBR & $\begin{array}{c}\text { VCR } \\
\left(\text { cell }^{-1} d^{-1}\right)\end{array}$ & Source \\
\hline Tampa Bay & May-Auga, ${ }^{\mathrm{a}, \mathrm{e}}$ & $1.0-3.0$ & $3.1-5.6$ & $2.2-7.0$ & & Jiang \& Paul (1994) \\
\hline Tampa Bay & May-Aug ${ }^{\mathrm{a}, \mathrm{e}}$ & $0.3-1.7$ & $3.5-6.6$ & $0.8-4.7$ & & Cochran \& Paul (1998) \\
\hline Northern Adriatic Sea & May-Aug ${ }^{\text {b,e }}$ & $0.5-3.8$ & $1.5-7.6$ & $5.4-19.0$ & & Weinbauer et al. (1995) \\
\hline $\begin{array}{c}\text { Chesapeake Bay top water } \\
\text { bottom water }{ }^{\mathrm{d}, \mathrm{e}}\end{array}$ & Jun-Aug ${ }^{\mathrm{c}, \mathrm{e}}$ & $\begin{array}{l}1.7-5.1 \\
1.0-3.2\end{array}$ & $\begin{array}{l}1.9-11.7 \\
1.7-5.9\end{array}$ & $\begin{array}{l}2.3-22.4 \\
2.2-10.9\end{array}$ & & Wommack et al. (1992) \\
\hline Gulf of Mexico coastal water & Jun & $0.5-0.7$ & $0.6-1.0$ & & $3-4$ & Wilhelm et al. (1998) \\
\hline Ria de Aveiro (tidal lagoon) & May-Sep & $2.4-25.0$ & $1.9-10.6$ & $4.7-55.6$ & & Almeida et al. (2001) \\
\hline $\begin{array}{l}{ }^{a} \text { Fig. } 1 \text { of their study } \\
{ }^{b} \text { Fig. } 2 \text { of their study } \\
\text { 'Fig. } 3 \text { of their study (data from } \\
\text { dFig. } 3 \text { of their study (data from } \\
\text { e Data were read } 3 \text { times from }\end{array}$ & $\begin{array}{l}\text { a range of } 4.5 \\
\text { a range of } 0.6 \\
\text { enlarged figur }\end{array}$ & $\begin{array}{l}5 \text { to } 9.4 \mathrm{mg} \mathrm{O}_{2} \mathrm{l}^{-1} \text { ) } \\
6 \text { to } 3.3 \mathrm{mg} \mathrm{O}_{2} \mathrm{l}^{-1} \text { ) } \\
\text { ires with a } 500 \mu \mathrm{m}\end{array}$ & & & & \\
\hline
\end{tabular}


HNF-induced bacterial mortality was much greater than that mediated by viruses. Similarly, Guixa-Boixereu et al. (1999) reported that bacterivory peaked immediately after a phytoplankton bloom when BA was maximal. As bacterivory is known as a major factor regulating BA in common marine systems (Sherr et al. 1989, Pedrós-Alió et al. 2000), bacterivory might also be responsible for controlling bacterial losses in eutrophic bay waters. However, it could be possible that the $24 \mathrm{~d}$ sampling interval between May and June might have missed a chance for observing high viral mortalities of bacteria, which might be expected after high HNF grazing (Guixa-Boixereu et al. 1999). Furthermore, when HNF grazing rate was reduced (3- to 16-fold) significantly in late August in low salinity hypoxic zone, contributions of viruses to bacterial mortality did not increase as postulated in other studies (Weinbauer \& Peduzzi 1995, Weinbauer \& Höfle 1998, Fisher \& Velimirov 2002). One of the reasons for this could be that short-term changes in bacterivory are not followed immediately by an increase in viral infection rates. In ad-
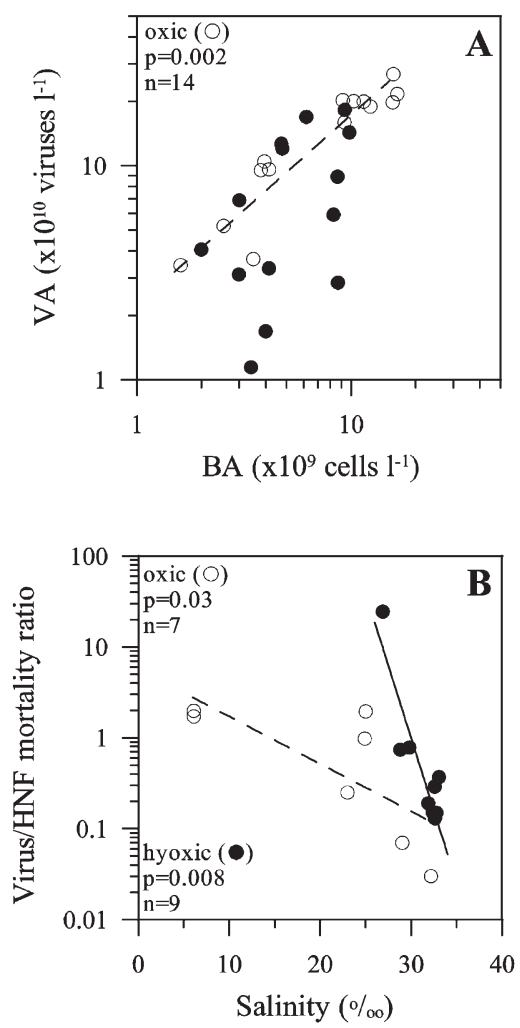

Fig. 3. Correlation of (A) bacterial abundance (BA) and viral abundance (VA), and (B) salinity and the ratios of bacterial mortality due to viruses and to heterotrophic nanoflagellates (HNF) grazing (virus:HNF mortality ratio). Broken and solid lines represent significant regression lines (derived from Model II regression analysis) for oxic ( $(\circ)$ and hypoxic $(\bullet)$ samples, respectively dition, other factors may be responsible for the conditions observed in the hypoxic zone in late August. The encounter rates between bacteria and viruses in the hypoxic zone were mostly much lower (2- to 10-fold) in late August compared to those in May and June (Table 1). Furthermore, at least 1 order of magnitude increases in aminopeptidase activities occurring at the same time (C. Y. Hwang unpubl. data) could have increased the decay of viruses and thus, decreased infectivity of viruses (Noble \& Fuhrman 2000).

\section{Comparisons with other studies and methodological considerations}

The observed VA values in Masan Bay in May (Table 1) are among the highest observed in coastal environments (Table 2). The high level of VA values in Masan Bay in May and June indicate that the bay was often highly eutrophic (Wommack et al. 1992, Weinbauer et al. 1993). This is in accordance with the high chl a concentrations found in May, and the high BA found in May and June. High BA and VA in May and June consequently led to high viral contact rates of bacteria (Table 1), which were much higher than those observed in coastal waters (Table 2) and higher than or similar to those observed in eutrophic lakes (49 to 180 cell $^{-1} \mathrm{~d}^{-1}$, Weinbauer \& Höfle 1998; 91 to 230 cell $^{-1} \mathrm{~d}^{-1}$, Fisher \& Velimirov 2002). However, high encounter rates between bacteria and viruses did not apparently result in high bacterial mortality due to viruses during the study (Fig. 2). The VA observed in this study could be high enough to represent a significant food source for HNF (González \& Suttle 1993). The data suggest that in May and June, HNF grazing on viruses could be a significant fraction of virus turnover (Table 1). In August, however, the role of HNF grazing in removing viruses seemed to be negligible. HNF may play a significant role in virus turnover when HNF grazing rates were very high (Table 1).

Discussions about interpreting the estimation of virus production based on FVIB by using the whole cell approach are detailed in Weinbauer \& Höfle (1998), Guixa-Boixareu et al. (1996, 1999) and Steward et al. (1996), and thus, will not be reiterated here. However, one point will be made: Since generally 300 to 500 cells were examined for counting the infected cells, and since from 0.3 to $5 \%$ of examined cells were infected, FVIB values in the lower range would be error-prone due to the rarity of infected cells. FVIB detected in our study were mostly comparable to those found in other coastal waters (0.2 to $4.6 \%$; Wommack \& Colwell 2000). As viral production rates are calculated using bacterial production measurements, some high estimates of virus production in our study are likely due to our high bac- 
terial production rates. Since bacterial productions were corrected for pool size of isotope dilution measured, our estimates of bacterial production, and thus, viral production and turnover time should be reliable.

In conclusion, high abundances of viruses and bacteria, and similar FVIB were observed in hypoxic and surface waters in the bay during the summer. In spite of widely changing conditions in the bay, viruses seemed to exert a constant control on bacteria in the water column, as indicated by $<3$-fold variations of VBR and the relatively constant mortality of bacteria by viruses. In temperate regions, where most rainfall occurs in summer, low salinity conditions would be predictable in bay environments, and reduced HNF grazing activities but steady viral loop conditions could prevail as in Masan Bay.

Acknowledgements We thank Dr. C. S. Chung (KORDI) for use of chl a data. We thank Dr. G. Bratbak and 2 anonymous reviewers for constructive and helpful comments, and Dr. M. Weinbauer for valuable comments and linguistic corrections of our revised manuscript. This study was supported (in part) by the BK 21 project of the Korean Government.

\section{LITERATURE CITED}

Almeida MA, Cunha MA, Alcântara F (2001) Loss of estuarine bacteria by viral infection and predation in microcosm conditions. Microb Ecol 42:562-571

Binder B (1999) Reconsidering the relationship between virally induced bacterial mortality and frequency of infected cells. Aquat Microb Ecol 18:207-215

Bloem J, Bär-Glissen MJB, Cappenberg TE (1986) Fixation, counting, and manipulation of heterotrophic nanoflagellates. Appl Environ Microbiol 52:1266-1272

Bratbak G, Heldal M, Thingstad TF, Riemann B, Haslund OH (1992) Incorporation of viruses into the budget of microbial C-transfer: a first approach. Mar Ecol Prog Ser 83:273-280

Cho BC, Azam F (1988) Heterotrophic bacterioplankton production measurement by the tritiated thymidine incorporation method. Arch Hydrobiol Beih Ergebn Limnol 31: 153-162

Cochran PK, Paul JH (1998) Seasonal abundance of lysogenic bacteria in a subtropical estuary. Appl Environ Microbiol 64:2308-2312

Dera J (1992) Marine physics. Elsevier Science Publishers, New York

Ducklow HW, Kirchman DL, Quinby HL (1992) Bacterioplankton cell growth and macromolecular synthesis in seawater cultures during the North Atlantic spring phytoplankton bloom, May, 1989. Microb Ecol 24:125-144

Fenchel T, Kristensen LD, Rasmussen L (1990) Water column anoxia: vertical zonation of planktonic protozoa. Mar Ecol Prog Ser 62:1-10

Fischer UR, Velimirov B (2002) High control of bacterial production by viruses in a eutrophic oxbow lake. Aquat Microb Ecol 27:1-12

Fuhrman JA, Noble RT (1995) Viruses and protists cause similar bacterial mortality in coastal seawater. Limnol Oceanogr 40:1236-1242

González JM, Suttle CA (1993) Grazing by marine nanoflagellates on viruses and virus-sized particles: ingestion and digestion. Mar Ecol Prog Ser 94:1-10
Guixa-Boixareu N, Calderón-Paz JI, Heldal M, Bratbak G, Pedrós-Alió C (1996) Viral lysis and bacterivory as prokaryotic loss factors along a salinity gradient. Aquat Microb Ecol 11:215-227

Guixa-Boixareu N, Lysnes K, Pedrós-Alió C (1999) Viral lysis and bacterivory during a phytoplankton bloom in a coastal water microcosm. Appl Environ Microbiol 65:1949-1958

Jiang SC, Paul JH (1994) Seasonal and diel abundance of viruses and occurrence of lysogeny/bacteriocinogeny in the marine environment. Mar Ecol Prog Ser 104:163-172

Jin YH, Kim KT, Chung CS, Kim SH, Yang DB, Hong GH, Lee KW (2000) Behavior of trace metals in Masan Bay, Korea during oxygen deficient period. J Kor Soc Mar Environ Engin 3:56-64 (in Korean)

Moriarty DJW (1990) Techniques for estimating bacterial growth rates and production of biomass in aquatic environments. In: Brigorova R, Norris JR (eds) Methods in microbiology. Academic Press, London, p 211-234

Murray A, Jackson GA (1992) Viral dynamics: a model of the effects of size, shape, motion and abundance of singlecelled planktonic organisms and other particles. Mar Ecol Prog Ser 89:103-116

Noble RT, Fuhrman JA (1998) Use of SYBR Green I for rapid epifluorescence counts of marine viruses and bacteria. Aquat Microb Ecol 14:113-118

Noble RT, Fuhrman JA (2000) Rapid virus production and removal as measured with fluorescently labeled viruses as tracers. Appl Environ Microbiol 66:3790-3797

Noble RT, Steward GF (2001) Estimating viral proliferation in aquatic samples. In: Paul JH (ed) Methods in microbiology, Vol 30. Marine microbiology. Academic Press, London, p 67-83

Paerl HW, Pinckney JL, Fear JM, Peierls BL (1998) Ecosystem responses to internal and watershed organic matter loading: consequences for hypoxia in the eutrophying Neuse River Estuary, North Carolina, USA. Mar Ecol Prog Ser 166:17-25

Park JS, Cho BC (2002) Active heterotrophic nanoflagellates in hypoxic water-column of the eutrophic Masan Bay, Korea. Mar Ecol Prog Ser 230:35-45

Parsons TR, Maita Y, Lalli CM (1984) A manual of chemical and biological methods for seawater analysis. Pergamon Press, Oxford

Pedrós-Alió C, Calderón-Paz JI, Gasol JM (2000) Comparative analysis shows that bacterivory, not viral lysis, controls the abundance of heterotrophic prokaryotic plankton. FEMS Microbiol Ecol 32:157-165

Porter KG, Feig YS (1980) The use of DAPI for identifying and counting aquatic microflora. Limnol Oceanogr 25:943-948

Proctor LM, Okubo A, Fuhrman JA (1993) Calibrating estimates of phage-induced mortality in marine bacteria: ultrastructure studies of marine bacteriophage development from one-step growth experiments. Microb Ecol 25: 161-182

Seki H (1991) Microbial energetics in marine hypoxic water. Mar Pollut Bull 22:163-164

Sherr BF, Sherr EB, Fallon RD (1987) Use of monodispersed, fluorescently labeled bacteria to estimate in situ protozoan bacterivory. Appl Environ Micobiol 53:958-965

Sherr BF, Sherr EB, Pedrós-Alió C (1989) Simultaneous measurement of bacterioplankton production and protozoan bacterivory in estuarine water. Mar Ecol Prog Ser 54: 209-219

Steward GF, Smith DC, Azam F (1996) Abundance and production of bacteria and viruses in the Bering and Chukchi Seas. Mar Ecol Prog Ser 131:287-300

Suttle CA (1993) Enumeration and isolation of viruses. In: 
Kemp PF, Sherr BF, Sherr EB, Cole JJ (eds) Handbook of methods in aquatic microbial ecology. CRC Press, Boca Raton, FL, p 127-129

Tuomi P, Kuuppo P (1999) Viral lysis and grazing loss of bacteria in nutrient- and carbon-manipulated brackish water enclosures. J Plankon Res 21:923-937

Weinbauer MG, Höfle MG (1998) Significance of viral lysis and flagellate grazing as factors controlling bacterioplankton production in a eutrophic lake. Appl Environ Microbiol 64:431-438

Weinbauer MG, Peduzzi P (1995) Significance of viruses versus heterotrophic nanoflagellates for controlling bacterial abundance in the northern Adriatic Sea. J Plankton Res 17:1851-1856

Weinbauer MG, Fuks D, Peduzzi P (1993) Distribution of

Editorial responsibility: Gunnar Bratbak,

Bergen, Norway viruses and dissolved DNA along a coastal trophic gradient in the northern Adriatic Sea. Appl Environ Microbiol 59:4074-4082

Weinbauer MG, Fuks D, Puskaric S, Peduzzi P (1995) Diel, seasonal and depth-related variability of viruses and dissolved DNA in the northern Adriatic Sea. Microb Ecol 30: $25-41$

Wilhelm SW, Weinbauer MG, Suttle CA, Jeffrey WH (1998) The role of sunlight in the removal and repair of viruses in the sea. Limnol Oceanogr 43:586-592

Wommack KE, Colwell RR (2000) Virioplankton: viruses in aquatic ecosystems. Microbiol Mol Biol Rev 64:69-114

Wommack KE, Hill RT, Kessel M, Russek-Cohen E, Colwell RR (1992) Distribution of viruses in the Chesapeake Bay. Appl Environ Microbiol 58:2965-2970

Submitted: December 12, 2001; Accepted: September 2, 2002 Proofs received from author(s): December 18, 2002 